\title{
SUSTAVI UPRAVLJANJA FONDOVIMA REGIONALNE POLITIKE EU U MALIM DRŽAVAMA - ISKUSTVA BALTIČKIH I OTOČNIH DRŽAVA I PRIMJENJIVOST NA HRVATSKU
}

\author{
Zvonimir Savić ${ }^{19}$
}

UDC / UDK: 332.14:339.96: 061.1EU(261.249)(497.5)

JEL classification / JEL klasifikacija: O52

DOI: https://doi.org/10.22598/pi-be/2021.15.2.121

Scientific review / Pregledni znanstveni rad

Received / Primljeno: August 25, 2021 / 25. kolovoza 2021.

Accepted for publishing / Prihvaćeno za tisak: October 8, 2021 / 8. listopada 2021.

\section{Sažetak}

Nacionalni sustavi koji omogućavaju neometano upravljanje $i$ efikasnu implementaciju fondova regionalne (kohezijske) politike EU, presudni su za uspjeh korištenja te politike u pojedinoj državi EU. Međutim, prostor za raznolikost u implementaciji i upravljanju regionalnom politikom EU je velik. Stoga se nacionalna iskustva razlikuju zbog brojnih faktora, poput intenziteta $i$ tipa EU financiranja, koherentnosti područja u koja se sredstva fondova EU usmjeravaju te relativne snage nacionalne administracije. Stoga sustavi implementacije mogu znatno odstupati među državama, a prikupljanje i obrada podataka za potrebe ovoga rada znatno je otežana zbog nejednake trensparentnosti $i$ dostupnosti podataka o arhitekturi nacionalnih institucionalnih sustava upravljanja fondovima EU. Rezultati istraživanja u ovom radu pokazali su da sustavi (arhitektura) upravljanja fondovima regionalne politike EU među državama nisu identični zbog cijelog niza faktora. Međutim, u analiziranim državama u ovom radu prisutne su i sličnosti, što je dijelom posljedica prijenosa iskustava među državama. Stoga rezultati istraživanja pokazuju da je moguće definirati optimalan $i$ funkcionalan nacionalni sustav upravljanja fondovima regionalne politike EU, temeljen na iskustvima usporedivih država te ga primijeniti i na Hrvatsku. S obzirom da se nalazimo na samom početku nove financijske perspektive EU (2021. - 2027.), kada se po državama članicama EU definiraju sustavi upravljanja fondovima EU za novu financijsku perspektivu, a objavljenih radova/istrživanja koji bi bili podloga takvim odlukama i na razini Hrvatske nema, time je doprinos $i$ vrijednost ovoga rada nositeljima politika pravovremen i značajan.

${ }^{19}$ Dr. sc. Zvonimir Savić, Glavni ekonomist, Hrvatska gospodarska komora, Zagreb, Hrvatska, E-mail: zsavic@hgk.hr 
Ključne riječi: Regionalna politika EU; sustavi upravljanja regionalne politike $E U$; isplate fondova EU; apsorpcija fondova $E U$.

\section{UVOD}

Nakon ulaska u EU, Hrvatska postaje 28. država u kojoj se provodi regionalna (kohezijska) politika EU, što podrazumijeva i potrebu razumijevanja koncepta regionalnog razvoja, ali i potrebu razvoja institucionalnog sustava $\mathrm{i}$ administrativnih kapaciteta za provedbu regionalne politike EU i apsorpciju sredstava koja su dodijeljena (alocirana) pojedinoj državi. Pritom je apsorpcijski kapacitet određen trima glavnim činiteljima:

1. administrativnim (institucionalnim) ustrojstvom i kapacitetima za provođenje operativnih programa (strateških dokumenata koji definiraju nacionalne razvojne potrebe koje će se sufinancirati sredstvima fondova EU);

2. financijskim kapacitetom sufinanciranja projekata financiranih iz fondova EU;

3. makroekonomskim kapacitetima države da osigura dovoljno produktivnih investicijskih prilika za efikasno korištenje fondova EU.

U središtu pažnje ovoga rada je prvi gore spomenuti činitelj (institucionalno ustrojstvo). Naime, apsorpcijski kapaciteti ponajviše ovise o institucionalnim činiteljima, odnosno o tome u kojoj su mjeri vlasti na središnjoj (kao i regionalnoj i lokalnoj) razini sposobne pripremiti konzistentne višegodišnje planove korištenja fondova EU, a posljedično se i nositi i s velikom količinom administrativnog posla vezanog uz povlačenje sredstava fondova EU i uspješno koordinirati i nadzirati njihovo korištenje. U ovom radu nije zaobiđen ni teorijski okvir regionalne politike EU u drugom poglavlju, koji olakšava sagladavanje važnosti utjecaja sustava provedbe regionalne politike $\mathrm{u}$ kontekstu iskustava nekoliko odabranih država.

Kako bi iskustva nekih država u sustavu upravljanja fondovima regionalne politike EU bila što je moguće više usporediva s Hrvatskom, bitno je imati u vidu i veličinu neke države, odnosno veličinu njenog gospodarstva, relativnu razinu razvijenosti u odnosu na druge države EU te razinu administrativne centraliziranosti u provedbi projekata i programa.

Stoga prikaz sustava implementacije u ovome radu obuhvaća pet država (Latvija, LItva, Estonija, Malta i Cipar), pri čemu su kriteriji za odabir država za prikaz u ovome radu sljedeći:

- Države iz posljednjeg vala proširenja EU

- Države slične ili manje veličine kao Hrvatska (površina i broj stanovnika)

- Države sa sličnim ili manjim brojem NUTS 2 regija kao Hrvatska

- Države slične ili manje alokacije sredstava regionalne politike EU kao Hrvatska (2014. - 2020., u ukupnom iznosu)

- Države slične ili manje alokacije sredstava regionalne politike EU kao Hrvatska (2014. - 2020., po stanovniku - p/c)

- Države korisnice sredstava Kohezijskog fonda 
- Države slične razine razvijenosti kao Hrvatska (u pretkriznoj 2008. godini i u zadnjoj dostupnoj po podacima 2019.)

\section{REGIONALNA POLITIKA EU I NJEZINI FONDOVI KAO INSTRUMENTI PROVEDBE}

Neminovna je činjenica kako postoji izuzetna raznolikosti između europskih regija prema gotovo svim ekonomskim, ali i ostalim čimbenicima, stoga je veliki izazov na razini EU po pitanju strukturnih politika i konvergencije. Kohezija se postiže uglavnom promocijom uvjeta za povećanje ekonomskog rasta i smanjenjem nejednakosti, što su ciljevi europske regionalne politike (Monfort, 2008.).

Značajno pozitivan utjecaj duljine članstva u EU na ekonomski rast dokazali su Crespo i suradnici 2008. godine, a posebno zanimljiv zaključak njihovog istraživanja jest za zemlje koje su značajno više zaostajale prije ulaska u EU i ekonomskog prosperiteta nakon ulaska u EU (Strielkowski i Höschle, 2013.; Jakubowski, 2018.; Zbigniew i Mariusz, 2004.). Martin, Veláquez i Funck (2001.), Radulović i Kostić, 2020., Borović et al., 2020.) u svojem istraživanju donose vrijedne zaključke, u kojem se posebice ističe jedan koji naglašava da su, osim visokih transfera iz EU, nužni efikasni i ostali faktori razvoja poput makroekonomske stabilnosti, efikasnog institucionalnog okvira, konkurencije i mobilnosti radne snage što potvrđuje kako integracija u EU može biti od iznimne koristi za konvergenciju, ali ona nije zamjena za pojedine nacionalne politike koje nužno moraju biti što efikasnije.

Arratibel i ostali (2007.) potvrdili su kako su, nakon proširenja 2004. godine, nove članice EU uspjele povećati njihovu relativnu razinu dohotka po glavi stanovnika (uključivši i rast produktivnosti zbog rasta ukupne faktorske produktivnosti) iako su ostali brojni drugi izazovi (posebice s radnom snagom - migracijama i reformama). Dokazi za tzv. „uvjetnu konvergenciju“ značajno su slabiji za tranzicijske ekonomije, ističu Borys, Polgár i Zlate (2008.) i naglašavaju kako klasična teorija rasta (temeljena na rastu BDPa po stanovniku, obrazovanju, stopi ulaganja i slično) gotovo nije imala utjecaja na tranzicijske zemlje (novije članice EU).

Gospodarska i politička integracija među članicama Europske unije podrazumijeva da te države moraju donositi i provoditi zajedničke odluke o brojnim pitanjima, što je dovelo da razvoja zajedničkih politika. Odnosi EU s ostatkom svijeta također su postali važni, što je dovelo do razvoja zajedničke vanjske i sigurnosne politike. Ascani, Crescenzi i Iammarino (2012.) analizirajući brojna znanstvena istraživanja pronalaze poveznice između ekonomskih integracija, teorije o međunarodnoj trgovini i pitanjima lokacije, ali i podsjećaju na Kaldorovo istraživanje iz 1970. godine koje naglašava, već tada, štetne učinke ekonomskih integracija na manje razvijene regije u odnosu na one koje su u samom početku integracije bile puno razvijenije.

U suvremeno doba, uzimajući u obzir kontekst EU, kako su rasle potrebe, tako su se razvijale i zajedničke politke, od kojih se mogu izdvojiti iduće: Regionalna politika Europske unije, prometna politika, zajednička poljoprivredna politika, politika zaštite okoliša, socijalna politika, ekonomska i monetarna unija, politika tržišnog natjecanja te 
potrošačka politika Europske unije. Bogunović ističe (2001.) kako je zadaća regionalne razvojne politike omogućavanje regijama da ostvare svoj potencijal i iskoriste mogućnosti za održiv razvoj. U tome, ključnu dimenziju predstavlja država koja je, putem svojih instrumenata, glavni dominantni koordinator i regulator ekonomskih aktivnosti unutar nacionalnog gospodarstva i mora ostvariti kvalitetan dijalog, sinergiju i koordinaciju između bottom-up političkih razina na nacionalnoj, ali i nadnacionalnoj razini (Bianchi, 2006.). Maskell (1998.) ističe kako regionalna politika ovisi o specifičnom kontekstu i posebnosti gospodarske strukture regije. Regionalna politika EU može se definirati kao investicijska politika čiji je cilj promicanje ukupnog ravnomjernog razvoja država članica EU i njihovih regija. Regionalna politika je i iskaz solidarnosti EU s manje razvijenim državama i regijama, pri čemu se financijska sredstva usmjeravaju u područja i sektore u kojima su najpotrebnija. Uz navedeno, cilj regionalne politike EU je smanjivanje značajnih teritorijalnih, socijalnih i ekonomskih u europskim regijama.

Kako ističu Ferry i McMaster (2013, str. 1504), regionalna politika može promicati promjene unutarnje politike pružanjem dodatnog izvora financiranja za regionalni razvoj, uz obavezan okvir koji regulira sadržaj, upravljanje i provedbu politike. Da bi zadovoljile minimalne kriterije upravljanja sredstvima pomoći EU, naglašavaju Frkić i Rek (2004., u: Drvenkar, 2012.) države moraju definirati sustav za upravljanje EU fondovima, odnosno sustav za njihovu provedbu (pri čemu je prikaz sustava upravljanja fondovima regionalne politke u nekoliko odabranih država EU elaboriran u nastavku ovoga rada).

\section{PRIKAZ SUSTAVA UPRAVLJANJA FONDOVIMA REGIONALNE POLITIKE EU U POJEDINIM DRŽAVAMA - ISTRAŽIVANJE}

U tablici 1 s kriterijima za odabir država za potrebe usporedbe sustava implementacije fondova EU, bitno je za zamijetiti da se po ključnim pokazateljima države iz tablice ne razlikuju mnogo u odnosu na Hrvatsku. To se prvenstveno odnosi na sličnu alokaciju sredstava regionalne politike po stanovniku, razinu razvijenosti te sličan broj NUTS 2 regija. Time se stvaraju pretpostavke za pripremu i provedbu istraživanja koje za svaku državu obuhvaća bitne elemente sustava upravljanja i implementacije fondova EU.

Stoga je za svaku državu provedeno istraživanje s ciljem dobivanja idućih informacija za proračunsko razdoblje 2014. - 2020.:

- Broj (operativnih) programa (nacionalnih i regionalnih) u svakoj državi

- Raspoloživa sredstva regionalne (kohezijske) politike EU

- Arhitektura programa, odnosno nazivi i tematska područja operativnih programa

- Sredstva dodijeljena OP-ovima (operativnim programima)

- Napredak u implementaciji fondova

- Shema implementacijske strukture 
Prikupljeni podaci po državama po gore navedenim elementima daju vrlo solidan temelj za usporedbu kompleksnosti i efikasnosti pojedinih sustava upravljanja te programskih prioriteta. Nadalje, temeljem prikaza situacije u drugim, s Hrvatskom usporedivim državama, za očekivati je da se lakše mogu donijeti zaključci. Naime, usporednim prikazom po državama, pokušat će se zaključiti da li određeni sustav upravljanja fondovima EU te arhitektura samih programa u pojedinoj državi kolerira s efikasnošću upravljanja i apsorpcijom sredstava fondova EU. Osnovni pregled operativnih programa, dodijeljenih sredstava, ali i osnovne informacije o upravljačkim i koordinacijskim tijelima u odabranim državama, nalazi se u tablici 2 (Prikaz operativnih programa i dodijeljenih sredstava za razdoblje 2014. - 2020.). Dodatno, osnovna informacija o iskorištenosti sredstava Europskih strukturnih i investicijskih fondova u odabranim državama, nalazi se u grafu 1 (Napredak u implementaciji Europskih strukturnih i investicijskih fondova, isplaćeno kumulativno, \% u odnosu na planirano).

Tablica 1. Kriteriji za odabir država za potrebe usporedbe sustava implementacije fondova EU

\begin{tabular}{|c|c|c|c|c|c|c|c|}
\hline \multirow{2}{*}{ R. br. } & \multirow{2}{*}{ Kriteriji } & \multicolumn{6}{|l|}{ Država } \\
\hline & & HR & LV & LT & EE & MT & CY \\
\hline 1 & $\begin{array}{l}\text { Države iz posljednjeg vala } \\
\text { proširenja EU (godina proširenja) }\end{array}$ & 2013 & $2004^{*}$ & & & & \\
\hline 2 & $\begin{array}{l}\text { Države slične ili manje veličine } \\
\text { kao Hrvatska (000 km2) }\end{array}$ & 57 & $65^{*}$ & $65^{*}$ & $45^{*}$ & 0,3 & 9,2 \\
\hline 3 & $\begin{array}{l}\text { Države slične ili manje veličine } \\
\text { kao Hrvatska (stanovništvo u } \\
\text { mil., 2015.) }\end{array}$ & 4,2 & $1,9^{*}$ & $2,9^{*}$ & $1,3^{*}$ & 0,4 & $1,2^{*}$ \\
\hline 4 & $\begin{array}{l}\text { Broj NUTS regija } \\
\text { (NUTS1/NUTS2/NUTS3) }\end{array}$ & 1.2.2021 & $1 / 1 / 6^{*}$ & $1 / 1 / 10^{*}$ & $1 / 1 / 5^{*}$ & $1 / 1 / 2^{*}$ & $1 / 1 / 1^{*}$ \\
\hline 5 & $\begin{array}{l}\text { Države slične ili manje alokacije } \\
\text { sredstava Kohezijske politike } \\
\text { kao Hrvatska (za 2014. - 2020., } \\
\text { mlrd. EUR) }\end{array}$ & 8,6 & $4,5^{\star}$ & $6,8^{*}$ & $3,6^{*}$ & 0,7 & 0,7 \\
\hline 6 & $\begin{array}{l}\text { Države slične ili manje alokacije } \\
\text { sredstava Kohezijske politike } \\
\text { kao Hrvatska (za } 2014 . \text { - } 2020 ., \\
\text { po stanovniku, } 000 \text { EUR) }\end{array}$ & 2,5 & $2,8^{*}$ & $2,8^{*}$ & $3,4^{*}$ & $1,9^{*}$ & 1 \\
\hline 7 & $\begin{array}{l}\text { Države korisnice sredstava } \\
\text { Kohezijskog fonda [1] }\end{array}$ & DA & $\mathrm{DA}^{*}$ & & & & \\
\hline 8 & $\begin{array}{l}\text { Države slične razine razvijenosti } \\
\text { kao Hrvatska (BDP p/c, } \\
\text { 2008.g./2019.g.) [2] }\end{array}$ & 64 / 65 & $60 / 69^{*}$ & $64 / 84^{*}$ & $70 / 84^{*}$ & $81 / 100^{*}$ & $107 / 90 *$ \\
\hline 9 & $\begin{array}{l}\text { Zadovoljeni kriteriji/ukupni broj } \\
\text { kriterija }\end{array}$ & & $8 / 8$ & $8 / 8$ & $8 / 8$ & $5 / 8$ & $4 / 8$ \\
\hline
\end{tabular}

Izvor: Eurostat regional yearbook; Eurostat, Europska komisija; obrada autora.

*Zadovoljeni kriteriji (pokazatelj usporedive vrijednosti s pokazateljima za Hrvatsku). 
Napomena [1]: Za razdoblje 2014. - 2020., države korisnice Kohezijskog fonda su Bugarska, Hrvatska, Cipar, Češka Republika, Estonija, Grčka, Mađarska, Latvija, Litva, Malta, Poljska, Portugal, Rumunjska, Slovačka i Slovenija. http://ec.europa.eu/regional policy/en/funding/cohesion-fund/

Napomena [2]: Za BDP p/c izvor:

https://ec.europa.eu/eurostat/databrowser/view/tec00114/default/table?lang=en pristupljeno stranici: 31 . siječnja 2021.

Tablica 2. Prikaz operativnih programa i dodijeljenih sredstava za razdoblje 2014. 2020.

\begin{tabular}{|c|c|c|c|c|c|c|c|}
\hline \multirow{2}{*}{$\begin{array}{l}\text { R. } \\
\text { br. }\end{array}$} & & \multicolumn{6}{|c|}{ Država } \\
\hline & & Hrvatska & Latvija & Litva & Estonija & Malta & Cipar \\
\hline & $\begin{array}{l}\text { Broj programa Kohezijske } \\
\text { politike - nacionalnih }\end{array}$ & 2 & 1 & 1 & 1 & 3 & 2 \\
\hline 2 & $\begin{array}{l}\text { Broj programa Kohezijske } \\
\text { politike - regionalnih }\end{array}$ & & & & & & \\
\hline 3 & $\begin{array}{l}\text { Promjena broja OP-ova } \\
\text { Kohezijske politike u } \\
\text { odnosu na 2007-2013 }\end{array}$ & $\begin{array}{l}-2 \\
\text { (bilo 4) }\end{array}$ & & $\begin{array}{l}-2 \\
\text { (bilo 3) }\end{array}$ & $\begin{array}{l}-2 \\
\text { (bilo 3) }\end{array}$ & +1 & 0 \\
\hline 4 & $\begin{array}{l}\text { Raspoloživa sredstva - } \\
\text { Kohezijska politika, mil. } \\
\text { EUR }\end{array}$ & 8.463 & 4.418 & 6.709 & 3.535 & 707,9 & 702,4 \\
\hline 5 & Broj programa - EPFRR & 1 & 1 & 1 & 1 & 1 & 1 \\
\hline 6 & $\begin{array}{l}\text { Raspoloživa sredstva - } \\
\text { EPFRR, mil. EUR }\end{array}$ & 2.026 & 1.076 & 1.613 & 823,3 & 97,3 & 132,2 \\
\hline 7 & Broj programa - EFPR & 1 & 1 & 1 & 1 & 1 & 1 \\
\hline 8 & $\begin{array}{l}\text { Raspoloživa sredstva - } \\
\text { EFPR, mil. EUR }\end{array}$ & 252,6 & 139,8 & 63,4 & 101 & 22,6 & 39,7 \\
\hline 9 & Broj programa - ETS & 9 & 6 & 6 & 4 & 3 & 5 \\
\hline 10 & $\begin{array}{l}\text { Raspoloživa sredstva - } \\
\text { ETS, mil. EUR }\end{array}$ & 1.201 & 577,8 & 555,1 & 449,8 & 486,7 & 526,2 \\
\hline 11 & $\begin{array}{l}\text { Broj upravljačkih tijela } \\
\text { (ministarstava) za } \\
\text { implementaciju } \\
\text { Kohezijske politike }\end{array}$ & 2 & $\begin{array}{l}1 \\
\text { (Min. } \\
\text { financija) }\end{array}$ & $\begin{array}{l}1 \\
\text { (Min. } \\
\text { financija) }\end{array}$ & $\begin{array}{l}1 \\
\text { (Min. } \\
\text { financija) }\end{array}$ & $\begin{array}{l}1 \\
\text { (Min. za } \\
\text { europske } \\
\text { poslove) }\end{array}$ & \begin{tabular}{|l|}
1 \\
(DG for \\
european \\
programs)
\end{tabular} \\
\hline 12 & $\begin{array}{l}\text { Broj zaposlenih u } \\
\text { upravjjačkim tijelima* }\end{array}$ & $\begin{array}{l}158 \text { OPKK, } \\
65 \text { OPULJP, } \\
39 \text { EAFRD, } \\
45 \text { EMFF }\end{array}$ & $\begin{array}{l}\text { Informacija } \\
\text { javno } \\
\text { nedostupna. }\end{array}$ & $\begin{array}{l}1000 \text { in } \\
\text { ESIF } \\
\text { implemen } \\
\text { tation }\end{array}$ & $\begin{array}{l}\text { Informacij } \\
\text { a javno } \\
\text { nedostup } \\
\text { na. }\end{array}$ & 50 & 22 \\
\hline 13 & $\begin{array}{l}\text { Postojanje } \\
\text { koordinacijskog tijela* }\end{array}$ & \begin{tabular}{|l} 
DA \\
(Min. \\
regionalnoga \\
razvoja)
\end{tabular} & $\begin{array}{l}\text { DA (CFCA - } \\
\text { Min. } \\
\text { financija) }\end{array}$ & $\mathrm{NE}$ & $\mathrm{NE}$ & $\begin{array}{l}\text { DA } \\
\text { (Nac. } \\
\text { koordinaci } \\
\text { jski } \\
\text { odbor) }\end{array}$ & NE \\
\hline 14 & $\begin{array}{l}\text { Broj zaposlenih u } \\
\text { koordinacijskom tijelu* }\end{array}$ & 31 & $>300$ & & & 2 & \\
\hline
\end{tabular}

Izvor: Europska komisija, upravljačka tijela pojedinih država EU; obrada autora *EU Member States'Profiles, Annex 2 to the Final Report (2019 Ernst \& Young, s.r.o) 
Tablica 2 je usporedni prikaz sustava upravljanja fondovima regionalne politike po državama, što podrazumijeva i prikaz broja operativnih programa, raspoloživih sredstava, upravljačkih tijela i koordinacijskih tijela. Kako bi se mogla stvoriti jasnija i potpunija slika situacije u navedenim državama, u idućim potpoglavljima je obrađena svaka od pet odabranih država EU pojedinačno.

\subsection{Baltičke države: Latvija, Litva, Estonija}

\subsubsection{Latvija - sustav upravljanja ${ }^{20}$}

U financijskom razdoblju 2014. - 2020. Latviji je za provedbu regionalne politike EU na raspolaganju 4,4 milijarde eura (ukupan iznos pročaruna OP-ova: 5.192.801.939,00 eura, ukupan iznos EU sredstava: 4.418.233.214,00 eura - Kohezijski fond (KF): 1.349.414.695,00 eura, Europski fond za regionalni razvoj (EFRR): 2.401.252.452,00 eura, Europski socijalni fond (ESF): 609.544.789,00 eura ${ }^{21}$ ).

Iako su u novom financijskom razdoblju u sustavu upravljanja i kontrole identificirana čak 10 PT1 $^{22}$ (linijska ministarstva i Državni kancelarijat), njihov opseg nadležnosti je značajno smanjen u odnosu na prethodno financijsko razdoblje. (vidi u nastavku sliku 1: Latvija - shema implementacijske strukture)

Tijela za upravljanje fondovima EU u Latviji su: upravljačko tijelo, posredničko tijelo razine 1 (odgovorno tijelo), posredničko tijelo razine 2 (tijelo za suradnju), tijelo za reviziju, tijelo za ovjeravanje. odbor za praćenje, ured za praćenje nabave. Upravljačko tijelo je Ministarstvo financija ${ }^{23}$ : koje je odgovorno za učinkovito i transparentno korištenje EU fondova.

Odgovorna tijela izvršavaju dužnosti posredničkih tijela razine 1 (PT1): uključena su u planiranje dokumenata, utvrđuju kriterije odabira, provode postupke odabira projekata i evaluaciju provedbe projekata, aktivnosti nadzora i kontrole, analiziraju probleme u sustavu provedbe fondova i projekata te dostavljaju Upravljačkom tijelu i Odboru za praćenje prijedloge unaprjeđenje. Funkciju ovih tijela u sustavu upravljanja i provedbe EU fondova u Latviji obavljaju: Ministarstvo pravosuđa, Ministarstvo kulture, Ministarstvo socijalne skrbi, Ministarstvo znanosti i obrazovanja,

${ }^{20}$ Zakon o upravljanju Strukturnim i Kohezijskim fondom za programsko razdoblje 2014. - 2020; dostupno na: http://likumi.lv/doc.php?id=267471\&cs=f521ff1e; Latvijska središnja internetska stranica vezana uz ESI fondove, dostupno na: http://www.esfondi.lv/sakums; Latvijska Komunikacijska strategija za Europske strukturne i kohezijski fond u programskom razdoblju 2014 - 2020, dostupno na: https://komitejas.esfondi.lv/Shared\%20Documents/Communication strategy ENG fina $123072015 . \mathrm{pdf}$

${ }^{21}$ Dostupno na: http://ec.europa.eu/regional_policy/en/atlas/programmes/20142020/latvia/2014lv16maop001

${ }^{22}$ Posrednička tijela prve razine

${ }^{23}$ Dostupno na:

http://www.fm.gov.lv/en/s/es_un_arvalstu_finansu_palidziba/es_fondu_vadosa_iestade/ 
Ministarstvo prometa, Ministarstvo zaštite okoliša i regionalnog razvoja, Ministarstvo zdravstva, Ministarstvo gospodarstva, Ministarstvo poljoprivrede, Državni kancelarijat (Državni kancelarijat je središnja institucija javne administracije izravno podređena Premijeru).

Posrednička tijela (PT1): 11 PT1 identificirano je unutar provedbene strukture 10 ministarstava i državni ured. Sve su ove institucije podložne Ministarstvu financija u području provedbe ESIF-a. PT1-i nisu uspostavljeni isključivo u svrhe ESIF-a.

Posredničko tijelo (PT2): Jedino posredničko tijelo u Latviji je Središnja agencija za financiranje i ugovaranje (SAFU), koja je podređena Ministarstvu financija. U prethodnom financijskom razdoblju SAFU je obavljala funkciju PT2 za čak šest linijskih ministarstava, a u novom razdoblju preostala kao jedino PT2 tijelo u Sustavu upravljanja i kontrole EU fondovima.

Sustav upravljanja fondovima EU u Latviji organiziran je u skladu sa Zakonom o upravljanju strukturnim i kohezijskim fondom za programsko razdoblje 2014. - $2020 .{ }^{24}$ Ovaj zakon, iz 2014. godine, postavlja glavna načela za sustav upravljanja fondovima, utvrđuje prava i obveze institucija i korisnika.

Slika 2. Latvija - shema implementacijske strukture

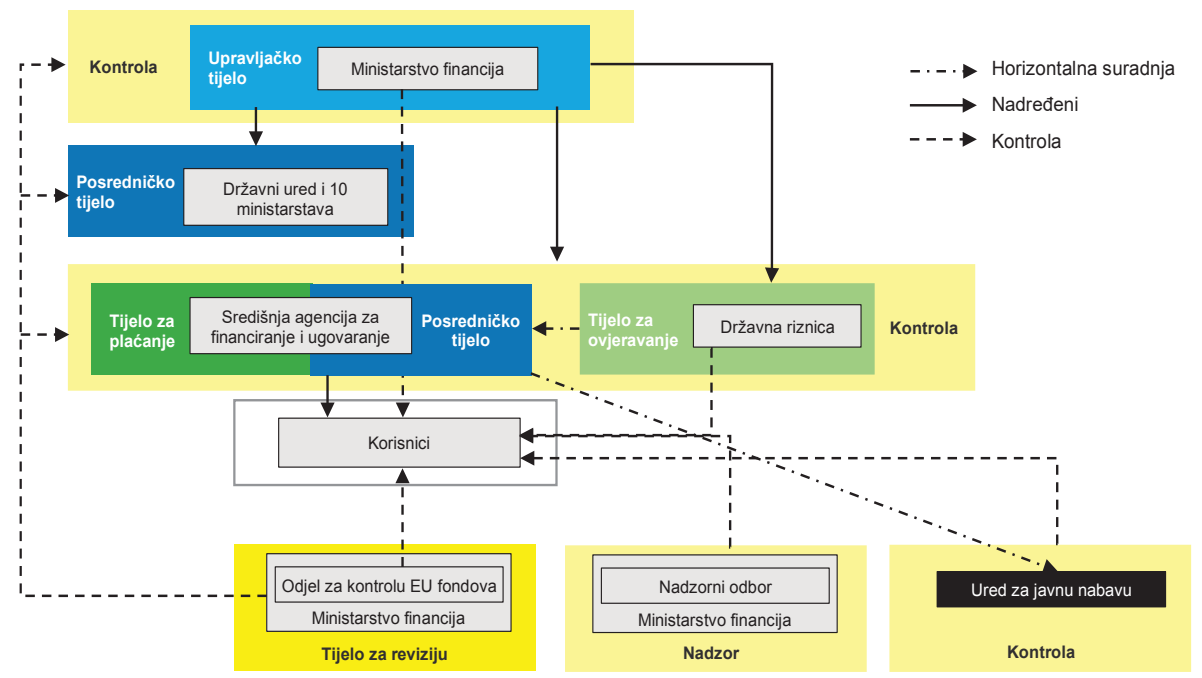

Izvor: Background study for the Preparation of the Implementation Structure for the 2021+ Period, final report (Annex 2 to the Final Report), Ernst \& Young s.r.o., 2019. ; obrada autora.

Gore navedena shema implementacijske strukture (vidi sliku 1: Latvija - shema implementacijske strukture), odnosno sustava upravljanja fondovima regionalne politike

${ }^{24}$ Dostupno na:http://likumi.lv/doc.php?id=267471 
EU u Latviji za proračunsko razdoblje EU 2014. - 2020., pokazuje sustav koji je značajnije centraliziran nego što je bio u prethodnom proračunskom razdoblju. Naime, Latvija je analizom nedostataka i naučenih lekcija napravila osjetne promjene u sustavu. Primjerice, uspostavljeno je samo jedno upravljačko tijelo (u odnosu na dotadašnjih sedam), značajno je sužen opseg nadležnosti posredničkih tijela te su dužnosti jasnije definirane, a broj posredničkih tijela druge razine smanjen je na jedan.

\subsubsection{Litva - sustav upravljanja ${ }^{25}$}

Litvi je u razdoblju 2014. - 2020. za provedbu regionalne politike EU na raspolaganju 6,7 milijardi eura ${ }^{26}$, uključujući 31,8 mil. eura za posebnu alokaciju za Inicijativu za zapošljavanje mladih (eng. Youth Employment Initiative - YEI) i 113,7 mil. eura za teritorijalnu suradnju. Dodatnih 1,6 mlrd. eura usmjerava se na razvoj poljoprivrednog sektora i ruralnog podučja iz Europskog poljoprivrednog fonda za ruralni razvoj (EPFRR). Alokacija za Europski fond za pomorstvo i ribarstvo (EFPR) doseže 63 mil. eura. Bitno je naglasiti da se, u Kontekstu regionalne politike, cijela Litva smatra manje razvijenom regijom.

Upravljačka tijela (UT): U Litvi postoje 3 OP-a kojima upravljaju dva UT-a. Odjel za upravljanje Europskom unijom je MA u slučaju OP-a koji se financira iz ESIFa. Ministarstvo poljoprivrede je MA za Program ribarstva i Program ruralnog razvoja. Do kraja 2017. više od 1.000 zaposlenika radilo je na implementaciji ESIF-a.

Posrednička tijela (PT1): U Litvi postoji ukupno 28 PT1: 9 ministarstava, 10 regionalnih vijeća za razvoj, 1 odjel za regionalni razvoj, 5 provedbenih agencija, 3 globalne uprave grantovima. Potrebno je naglasiti i da je Litva jedna od rijetkih država koja nema koordinacijsko tijelo.

EFRR, ESF i Kohezijski fond dio su jednog programa kojim upravlja Ministarstvo financija. EPFRR i EFPR imaju zasebne programe, ali obama fondovima upravlja Ministarstvo poljoprivrede. Upravljačka tijela kao članovi sudjeluju u odborima za praćenje ostalih upravljačkih tijela, čime se osigurava bliska koordinacija među europskim strukturnim i investicijskim fondovima. Sustav upravljanja i kontrole EU fondovima u Litvi uređen je „Odlukom Vlade o odgovornosti i podijeli funkcija između institucija u provedbi akcijskih programa ulaganja iz strukturnih fondova EU 2014. 2020.“27. Odluka Vlade definira i razdvaja funkcije i odgovornosti institucija u sustavu upravljanja i kontrole ESI fondova 2014. - 2020. i drugih tijela javne uprave koja sudjeluju u provedbi OP-a. Na taj način se želi osigurati učinkovita suradnja između institucija u sustavu upravljanja i kontrole, tijela javne uprave koja sudjeluju u provedbi OP-a i socijalnih i ekonomskih partnera kako bi se osiguralo njihovo aktivno sudjelovanje u donošenju transparentnih odluka u korištenju ESI fondova.

${ }^{25}$ Odluka Vlade o odgovornosti i podijeli funkcija između institucija u provedbi akcijskih programa ulaganja iz strukturnih fondova EU 2014. - 2020.; Dostupno na: https://www.etar.1t/portal/1t/legalAct/35957860f54a11e39cfacd978b6fd9bb

${ }^{26}$ Dostupno na:http://ec.europa.eu/regional_policy/en/funding/available-budget/

${ }^{27}$ Dostupno na: https://www.etar.lt/portal/lt/legalAct/35957860f54a11e39cfacd978b6fd9bb/VJUiZUeJsi 
Upravljačko tijelo u Litvi je Ministarstvo financija. Posrednička tijela su ministarstva i provedbene agencije. Ministarstva koja obavljaju funkcije posredničkih tijela razine 1, u skladu sa svojim nadležnostima su: Ministarstvo zaštite okoliša, Ministarstvo energetike, Ministarstvo kulture, Ministarstvo socijalne sigurnosti i rada, Ministarstvo prometa, Ministarstvo zdravlja, Ministarstvo obrazovanja i znanosti, Ministarstvo gospodarstva te Ministarstvo unutarnjih poslova.

Slika 3. Litva - shema implementacijske strukture

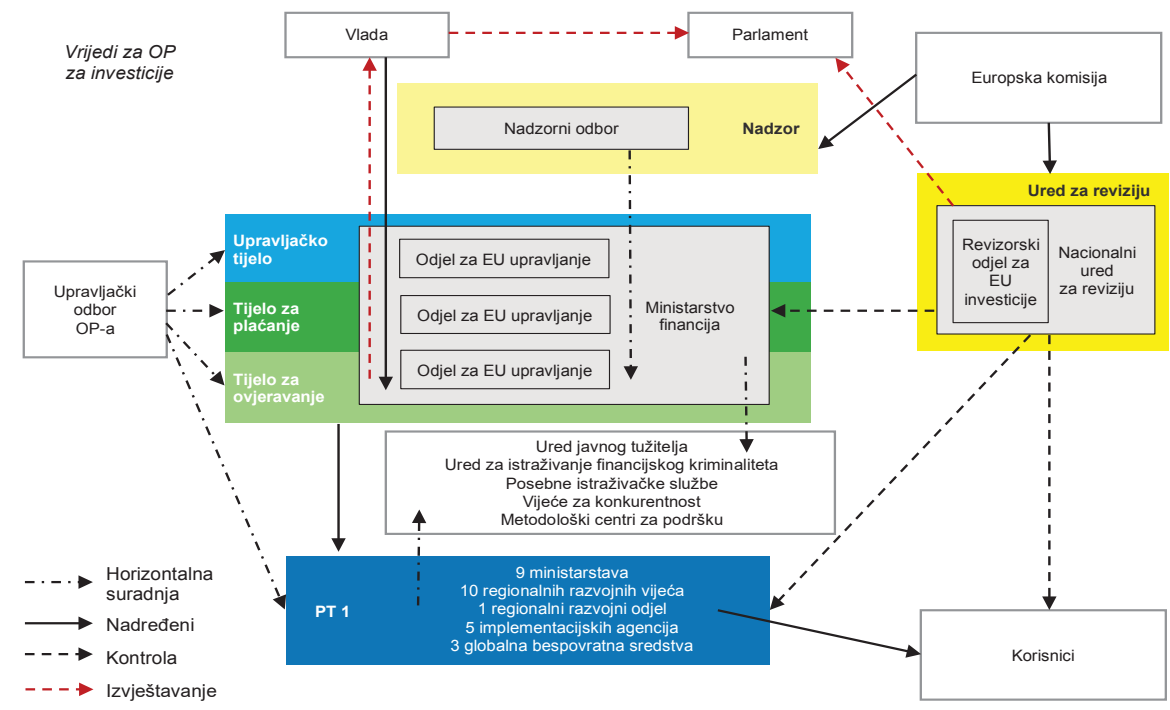

Izvor: Background study for the Preparation of the Implementation Structure for the 2021+ Period, final report (Annex 2 to the Final Report), Ernst \& Young s.r.o., 2019. ; obrada autora.

Gore navedena shema implementacijske structure (slika 2: Litva - shema implementacijske strukture), odnosno sustava upravljanja fondovima regionalne politike EU u Litvi za proračunsko razdoblje EU 2014. - 2020., pokazuje sustav koji je rezultat smanjenja broja operativnih programa (s tri na jedan). Naime, Litva je u prethodnom proračunskom razdoblju EU imala problema u funkcioniranju upravljačkih tijela su uspostavljena nova, što je podrazumijevalo izmještaj određenih funkcija i odgovornosti među ministarstvima i agencijama (primjerice, uspostava novih posredničkih). Kao i u slučaju ostalih Baltičkih država, upravljačko tijelo je Ministarstvo financija, što je u slučaju Litve bitno, jer zbog činjenice da nema koordinacijsko tijelo, upravljačko tijelo treba biti dovoljno jaka institucija, odnosno ministarstvo. 


\subsubsection{Estonija - sustav upravljanja ${ }^{28}$}

Za provedbu regionalne politike EU Estoniji je za proračunsko razdoblje 2014. - 2020. na raspolaganju 3,58 mlrd. eura ${ }^{29}$. Dodatnih 725,8 mil. eura usmjerava se iz Europskog poljoprivrednog fonda za ruralni razvoj (EPFRR). Alokacija za Europski fond za pomorstvo i ribarstvo (EFPR) doseže oko 100,9 mil. eura.

Temeljni akt koji regulira uspostavu sustava upravljanja i kontrole te tijela u sustavu i njihova prava i obveze u programskom razdoblju od 2014. do 2020. godine je Zakon o strukturnoj pomoći 2014. - 2020. Sustav upravljanja i kontrole za razdoblje 2014. - 2020. nije doživio veće promjene u odnosu na sustav u prethodnom razdoblju. Zakon o strukturnoj pomoći 2014. - 2020. u sustavu upravljanja i kontrole ESI fondovima utvrđuje sljedeća tijela: upravljačko tijelo, posredničko tijelo razine 1, posredničko tijelo razine 2, tijelo za ovjeravanje, tijelo za reviziju, centar kompetencija, odbor za praćenje OP-a, tematski odbori. Upravljačko tijelo je Ministarstvo financija.

U programskom razdoblju 2014. - 2020. godine, funkcije PT 1 obavljaju sljedeća tijela $^{30}$ : Ministarstvo ekonomskih poslova i komunikacija, Ministarstvo obrazovanja i istraživanja, Ministarstvo okoliša, Ministarstvo socijalnih poslova, Ministarstvo financija (za regionalna područja i za prioritet Unapređenje administrativnih kapaciteta), Ministarstvo unutarnjih poslova, Ministarstvo kulture (novo iz razdoblja 2014. - 2020.), Državni kancelarijat (novo iz razdoblja 2014. - 2020.). Podatak o njihovom broju zaposlenih nije javno dostupan.

Estonska Vlada je kao PT 2 odredila tijela izvršne vlasti ili pravne osobe vođene javnim ili privatnim pravom.

U skladu s čl. 123 (2) Uredbe (EU) 1303/2013, te kako je utvrđeno u „Operativnom programu za fondove kohezijske politike“, funkcije tijela za ovjeravanje obavlja UT, odnosno Ministarstvo financija. Tijelo za reviziju u skladu s čl. 123 (4) Uredbe (EU) 1303/2013 je Ministarstvo financija. National Coordination Authority (NCA) u Estoniji ne postoji. U Estoniji je za razdoblje 2014. - 2020. predviđen samo jedan program regionalne politike EU koji se financira iz više fondova, a u prethodnom ih je razdoblju imala tri. Ministarstvo financija upravljačko je tijelo, tijelo za ovjeravanje (njegove su funkcije bile spojene s funkcijama upravljačkog tijela) i tijelo za reviziju.

${ }^{28}$ Zakon o strukturnoj pomoći 2014. - 2020.; dostupno na: https:/www.riigiteataja.ee/en/eli/ee/Riigikogu/act/530112015002/consolide

Državni portal o e-uslugama; dostupno na: https://www.eesti.ee/est/

${ }^{29}$ Dostupno na:http://ec.europa.eu/regional policy/en/funding/available-budget/

${ }^{30}$ Dostupno na:http://www.struktuurifondid.ee/rakendusasutused/ 
Slika 4. Estonija - shema implementacijske strukture

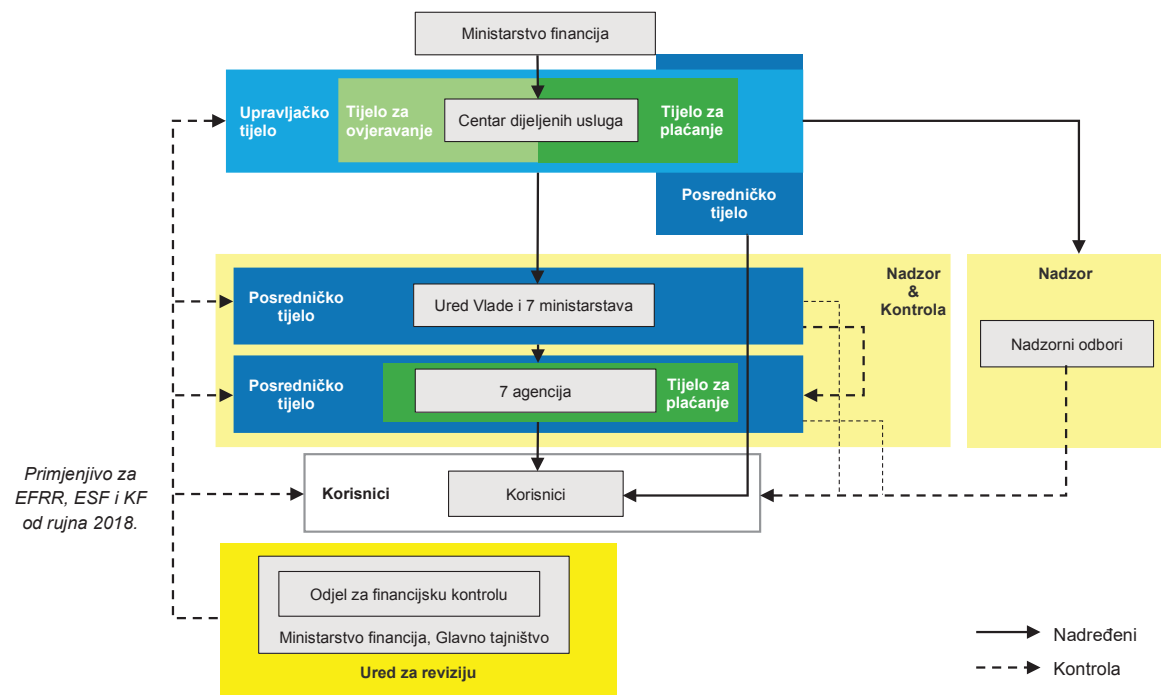

Izvor: Background study for the Preparation of the Implementation Structure for the 2021+ Period, final report (Annex 2 to the Final Report), Ernst \& Young s.r.o., 2019. ; obrada autora.

Napomena: Gore navedena shema u primjeni je od rujna 2018.

Shema implementacijske structure (vidi sliku 3: Estonija - shema implementacijske strukture), odnosno sustava upravljanja fondovima regionalne politike EU u Estoniji za proračunsko razdoblje EU 2014. - 2020., pokazuje sustav koji je centraliziraniji nego u prethodnom proračunskom razdoblju te je rezultat smanjenja operativnih programa s tri na jedan. Centralizacija je dijelom posljedica oslanjanja na Latvijska iskustva (Latvija je također centralizirala aktivnosti). Time je smanjeno administrativno opterećenje, što je bitno u provedbi fondova EU u manjim državama (od Malte, Cipra do Baltičkih država), gdje su ljudski resursi ograničeniji, a rizik obavljanja veće širine poslova izraženiji nego u većim državama. S obzirom da je dinamika korištenja fondova EU u Estoniji (ali i u Baltičkim državama) u pravilu bolja od ostalih promatranih država.

\subsection{Otočne države: Malta, Cipar}

\subsubsection{Malta - sustav upravljanja}

Za provedbu regionalne politike EU, Malti je za proračunsko razdoblje 2014. 2020. na raspolaganju oko 729 mil. eura, što uključuje 17 mil. eura za teritorijalnu suradnju. Dodatnih 97 mil. eura usmjerava se na razvoj poljoprivrednog sektora i ruralnih 
područja, a iz Europskog poljoprivrednog fonda za ruralni razvoj (EPFRR). Alokacija za Europski fond za pomorstvo i ribarstvo (EFPR) doseže 22,7 mil. eura.

Upravljačko tijelo (UT): Ministarstvo europskih poslova obavlja poslove Upravljačkog tijela svih operativnih programa, s „Coordination Department for Planning and Priorities“ kao upravljačko tijelo u slučaju nacionalnih programa te „Department of Funds and Programmes“"kao upravljačko tijelo u slučaju RDP-a and OPR-a.

Upravljačko tijelo za provedbu regionalne politike EU na Malti je Odjel za planiranje i koordinaciju prioriteta (eng. Planning and Priorities Coordination Division $P P C D)$ Ministarstva za europske poslove. Temeljne funkcije Odjela za planiranje i koordinaciju prioriteta (PPCD) ${ }^{31}$ su obavljanje poslova upravljačkog tijela za ESIF 2014. - 2020., potom funkcija upravljačkog tijela za SME Initiative te funkcija glavnog koordinatora za programiranje regionalne politike EU.

Tri programa koji se financiraju iz EFRR-a, KF-a i ESF-a provodit će isto upravljačko tijelo: Odjel za planiranje i koordinaciju prioriteta (eng. Planning and Priorities Coordination Division - PPCD) Ministarstva za europske poslove i provedbu izbornog manifesta (MEAIM) ${ }^{32}$.

Posrednička tijela (IB) uspostavljena su jedino u slučaju implementacije ERDFa i ESF-a: „Department of Measures and Support“, Ministarstvo za europske poslove te „Programming Statement“ za ERDF, potpom „Organization for Employment and Education“, vladina agencija pod okriljem Ministarstva obrazovanja i zapošljavanja, za ESF. Pojedinačna posrednička tijela imaju kompetencije koje se odnose na upravljanje pojedinačnih OP-ova, ovisno o fondu iz kojeg se financira. PT1 nisu osnovani specifično za potrebe ESIF-a.

Nacionalno koordinacijsko tijelo (NCA) je Međuvladin koordinacijski odbor, kojim koordinira Ministarstvo vanjskih poslova. Naime, tijelo odgovorno za koordinaciju i pripremu operativnih programa je Ured stalnog tajništva u Ministarstvu vanjskih poslova (eng. Office of the Permanent Secretary). Programima Strukturnih i Kohezijskog fonda, Europskog fonda za pomorstvo i ribarstvo te Europskog fonda za poljoprivredu i ruralni razvoj ${ }^{33}$, upravlja i koordinira Odjel za planiranje i koordinaciju prioriteta (eng. Planning and Priorities Coordination Division ) - za Strukturne i Kohezijski fond te Odjel za programe i fondove (eng. Funds and Programmes Division) - za Europski fond za poljoprivredu i ruralni razvoj, Europski fond za pomorstvo i ribarstvo te programe Europske teritorijalne suradnje. Ti odjeli nalaze se unutar Ministarstva za europske poslove. Takav centralizirani sustav za implementaciju ESI fondova i drugih financijskih

\footnotetext{
${ }^{31}$ Dostupno na:
}

https://eufunds.gov.mt/en/Operational\%20Programmes/Managing\%20Authority/Pages/ Managing-Authority.aspx\#

32 Dostupno na: https://eufunds.gov.mt/en/Pages/Home.aspx ;
https://eufunds.gov.mt/en/Operational\%20Programmes/Managing\%20Authority/Pages/ Managing-Authority.aspx

${ }^{33}$ Od siječnja 2014. programom financiranim iz EPFRR-a, upravlja i koordinira Odjel za programe $\mathrm{i}$ fondove unutar Ministarstva za europske poslove i provedbu izbornog manifesta 
inicijativa EU (uključujući Connecting Europe Facility) omogućuje koordinaciju različitih programa i inicijativa na nacionalnoj razini, a također smanjuje i rizik od dupliciranja ili preklapanja aktivnosti. ${ }^{34}$

Slika 5. Malta - shema implementacijske strukture

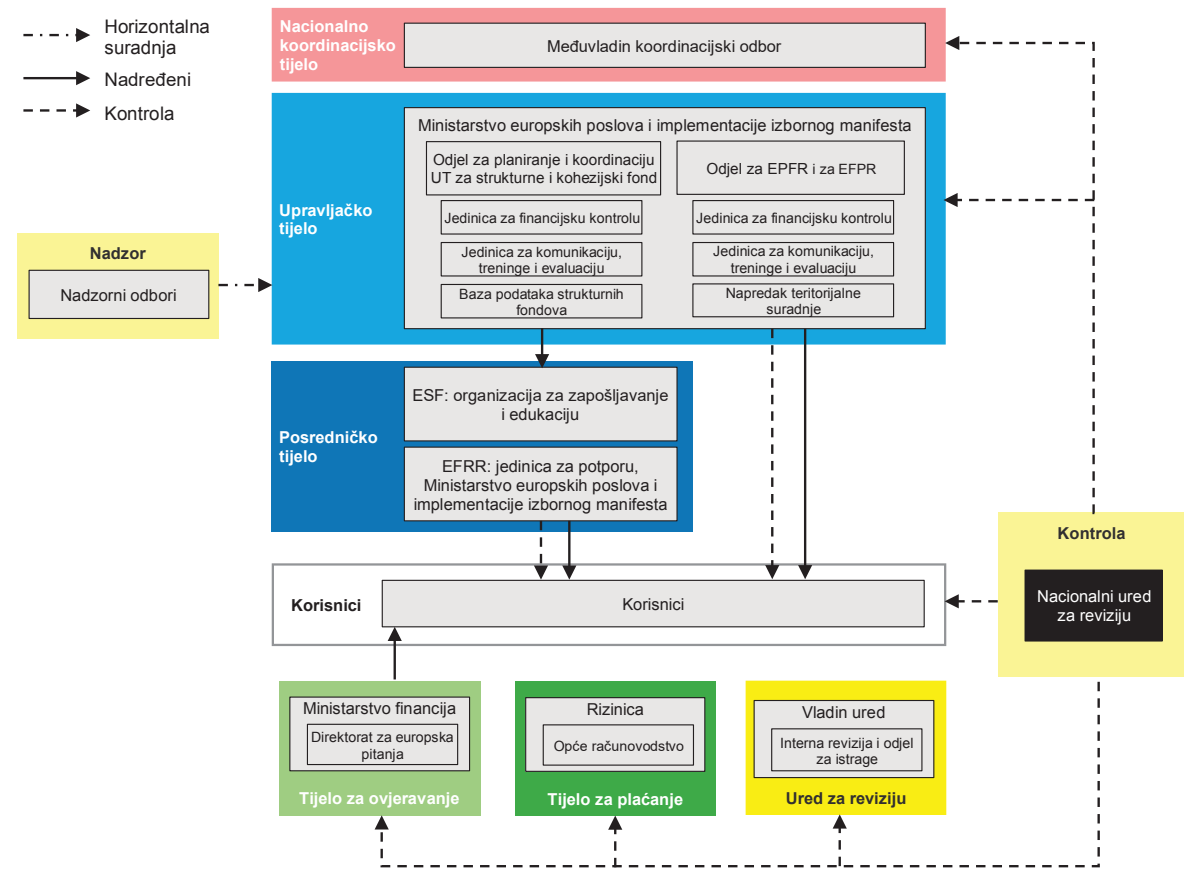

Izvor: Background study for the Preparation of the Implementation Structure for the 2021+ Period, final report (Annex 2 to the Final Report), Ernst \& Young s.r.o., 2019. ; obrada autora.

Shema implementacijske structure (vidi sliku 4: Malta - shema implementacijske strukture), odnosno sustava upravljanja fondovima regionalne politike EU u Malti za proračunsko razdoblje EU 2014. - 2020., pokazuje izraženo centralizirani sustav, što nije dalo prostora za veće promjene u sustava upravljanja. Za navedeno nije bilo niti veće potrebe, s obzirom da je riječ o najmanjoj državi koja je analizirana u ovom radu i po broju stanovnika, ali i po alokaciji sredstava fondova regionalne politke EU, a koja je u relativno dobroj poziciji u odnosu na ostale države u smislu dinamike korištenja fondova regionalne politike EU. Stoga nije bilo promjena u funkcionalnostima institucija.

${ }^{34}$ Partnership Agreement of Malta, 2014-2020, November 2014, str. 165 


\subsubsection{Cipar - sustav upravljanja}

Cipru je za provedbu regionalne politike EU za razdoblje 2014. - 2020. na raspolaganju 735,6 mil. eura (uključujući Europsku teritorijalnu suradnju) te 132,2 mil. eura za Ruralni razvoj. Sredstva za Europski fond za pomorstvo i ribarstvo (EFPR) iznose 39.715.209 eura. Dodatno, 11,6 mil. eura odnosi se na Inicijativu za zapošljavanje mladih 35 .

Upravljačka tijela (UT): Glavna uprava za europske programe, koordinaciju i razvoj (DG EPCD) je UT svih OP-ova, osim programa koji se financiraju iz EAFRD-a, a čiji je UT Ministarstvo poljoprivrede, ruralnog razvoja i okoliša. Broj programa u Cipru nije se promijenio u odnosu na razdoblje 2007. - 2013. U državi je uspostavljeno jedno upravljačko tijelo (Glavna uprava za europske programe, koordinaciju i $\operatorname{razvoj}^{36}$ ) i zajednički odbor za praćenje radi osiguranja koordinacije EFRR-a/KF-a i programa ESFa, a za sve te programe upotrebljava se jedinstveni informacijski sustav. DG EPCD je odgovoran i za korištenje i provedbu europskih programa i fondova u funkciji ${ }^{37}$ : nacionalnog tijela za regionalnu politiku i upravljačkog tijela za OP-ove sufinancirane od strane EFRR-a, ESF-a i KF-a.

Ulogu PT1 izvršavaju pojedina resorna ministarstva u vezi sa sufinanciranjem planova javnih nabava i programa dodjele nepovratnih sredstava, pojedine općine $\mathrm{s}$ obzirom na strateški okvir održivog urbanog razvoja i Državna riznica za kontrolu troškova javnih nabava. PT1 nisu posebno uspostavljeni za potrebe ESIF-a, oni su i dalje tijela državne uprave koja preuzimaju odabrane nadležnosti MA-a.

Nacionalno koordinacijsko tijelo (NCA) ne postoji, ali njegovu funkciju u određenoj mjeri obavlja Glavna uprava za europske programe, koordinaciju i razvoj, koja je UT za sve OP-ove, osim za programe financirane iz EAFRD-a.

${ }^{35}$ European Commission, Brussels, 20 June 2014, Summary of the Partnership Agreement for Cyprus, 2014-2020

${ }^{36}$ Directorate General for European Programmes, Coordination and Development - DG EPCD (Dostupno na: http://ec.europa.eu/regional_policy/en/atlas/managingauthorities//?search $=1 \&$ keywords=\&periodId=3\&countryCode=CY\&typeId=ALL http://www.dgepcd.gov.cy/dgepcd/dgepcd.nsf/index_en/index_en?OpenDocument ) ${ }^{37}$ Dostupno na: http://www.dgepcd.gov.cy/dgepcd/dgepcd.nsf/page05_en/page05_en?OpenDocument 
Slika 6. Cipar- shema implementacijske strukture
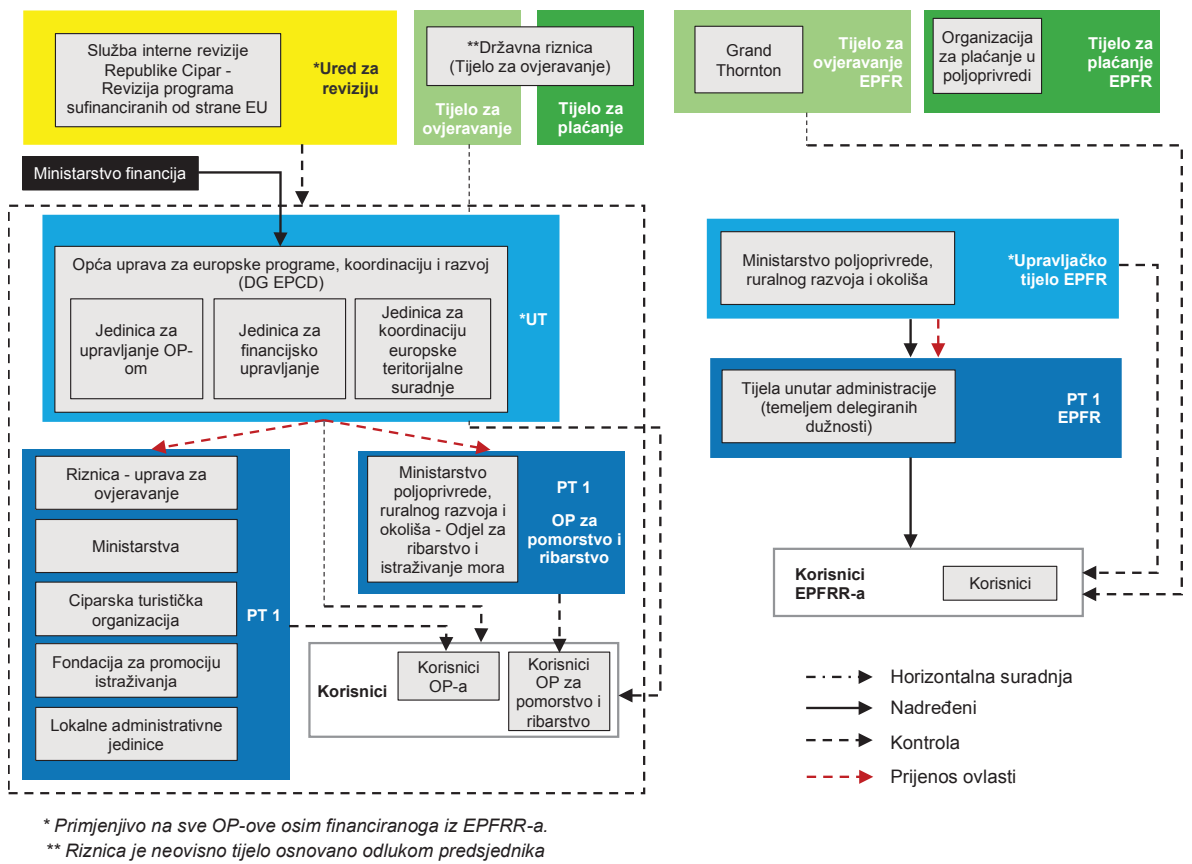

Izvor: Background study for the Preparation of the Implementation Structure for the 2021+ Period, final report (Annex 2 to the Final Report), Ernst \& Young s.r.o., 2019. ; obrada autora.

Gore navedena shema implementacijske structure (vidi sliku 5: Cipar - shema implementacijske strukture), odnosno sustava upravljanja fondovima regionalne politike EU u Cipru za proračunsko razdoblje EU 2014. - 2020., pokazuje sustav koji je centralizirao neke administrativne kontrole u odnosu na prethodno proračunsko razdoblje EU (s posredničkih tijela na državnu rzinicu), čime se smanjio pritisak na administrativne kapacitete. S obzirom na veličinu države i relativno malu alokaciju sredstava regionalne politike EU za Cipar, jače koncentriranje kompetencija u Ministarstvu financija, koje je ujedno i jedino upravljačko tijelo, pokazuje se kao primjerena odluka.

\section{ANALIZA NAPRETKA U ISPLATAMA SREDSTAVA FONDOVA EU}

Analiza napretka u implementaciji Europskih strukturnih i investicijskih fondova za proračunsko razdoblje 2014. - 2020. temelji se na podacima Europske komisije, koji su dostupni na godišnjoj razini (krajem kalendarske godine i zadnji dostupni kvartal) (vidi graf 1). Očekivano, stopa isplate sredstava u odnosu na ukupno 
planirana sredstva za svaku pojedinu državu su u prve dvije godine iznimno niske. Sporija financijska implementacija fondova EU na početku proračunskog razdoblja te početak ubrzavanja 2017. i 2018. godine, odnosno sredinom proračunskog razdoblja EU, slična je ubrzanju koje se zabilježilo i prethodno proračunsko razdoblje 2007. - 2013. Međutim, financijska implementacija u 2017. godini zaostaje gotovo godinu dana u odnosu na dinamiku u prethodnom proračunskom razdoblju ${ }^{38}$, uslijed čega je postotak isplata sredstava EU fondova razlog za zabrinutost, što stavlja dodatan pritisak na reviziju učinkovitosti sustava upravljanja fondovima EU.

Jedno od značajnih zapažanja je svakako vezano uz dinamiku isplata sredstava u Baltičkim državama. Naime, Estonija, Latvija i Litva su u prvom dijelu proračunskog razdoblja EU, prema podacima o isplatama sredstava europskih strukturnih i investicijskih fondova za kraj 2015., 2016. i 2017. godine, od deset promatranih država (uključujući Hrvatsku) bile među prva četiri mjesta (vidi graf 1). U idućim godinama te pozicije su zadržane te je krajem 2019. godine Estonija bila na prvom mjestu među deset analiziranih država, Litva na trećem mjestu te Latvija na četvrtom mjestu. Uređeniji i efikasniji sustav upravljanja fondovima EU u pojedinoj državi doprinosi stabilnosti i boljoj dinamici apsorpcije fondova EU, što je najvidljivije u Baltičkim državama.

Kroz vrijeme Malta i Cipar bilježe sve bolju dinamiku u implementaciji fondova EU (iako ne u potpunosti usporedivu jer Cipar zaostaje u prevedbi Kohezijskog fonda), što se može pripisati brojnim razlozima. Primjerice, zbog relativno male veličine gospodarstva i manjim potrebama za razvoj infrastrukture (nema potrebe za željezničkom infrastrukturom, podzemnim željeznicama niti za većim brojem zračnih luka), relativno je sužen ,izbor“" mogućih ulaganja, što utječe na usmjerenost sustava upravljanja na manji broj razvojnih prioriteta. To utječe na učinkovitost sustava upravljanja, koji se usmjerava na pripremu manjeg broja prioriteta te provedbu projekata iz manje tematskih područja, što u konačnici može utjecati na relativno stabilnu i dobru dinamiku ugovaranja i isplata sredstava fondova regionalne politike EU. Međutim, upravo s obzirom na veličinu tih država i njihove spomenute specifičnosti (najmanji broj stanovnika u odnosu na ostale analizirane države, najmanja alokacija sredstava fondova EU, nisu kontinentalne države, s time vezane potrebe financiranja...) nacionalni sustavi upravljanja fondovima EU na Malti i Cipru ne bi mogli u potpunosti poslužiti kao predložak za bilo koju preostalu državu, uključujući Hrvatsku.

S druge strane, znakovito je da od početka sedmogodišnjeg proračunskog razdoblja EU, tri Baltičke države bilježe solidne rezultate, odnosno nalaze se među natprosječno dobrim državama (od analiziranih deset - vidi graf 1) gledajući isplate sredstava fondova EU u odnosu na dodijeljena sredstva te stabilnost relativne pozicije $u$ odnosu na druge države. Za sve te tri države znakovito je da u sustavu upravljanja fondovima EU imaju samo jedno upravljačko tijelo za provedbu regionalne politike (u svim državama je to Ministarstvo financija) te da u slučaju Litve, postoji i koordinacijsko tijelo. Dodatno, sve tri države imaju samo po jedan nacionalni operativni program za provedbu regionalne politke. U slučaju Litve i Latvije, to je smanjenje za dva u odnosu

${ }^{38}$ Financial Implementation of European Structural and Investment Funds, Directorate General for Internal Policies of the Union, June 2018, str. 68. 
na prethodno proračunsko razdoblje (u razdoblju 2007. - 2013. obje države imale su po tri operativna programa za regionalnu politiku), dok je Latvija i u tom razdoblju imala jedan operativni program. Vrlo je znakovito da su promjene u sustavu upravljanja $u$ Estoniji za razdoblje 2014. - 2020. inspirirane Latvijskim modelom, odnosno Estonija je, po uzoru na Latviju, nastojala centralizirati sustav i administrativne procese učiniti efikasnijima. Primjerice, smanjila je broj operativnih programa s tri u razdoblju 2007. 2013. na jedan u razdoblju 2014. - 2020., a od rujna 2018. godine smanjila je broj posredničkih tijela za jedno, s osam na sedam. To nije značajna promjena, ali je dokaz da se i tijekom trajanja proračunskog razdoblja mogu vršiti promjene u sustavu upravljanja kako bi se povećala učinkovitost sustava upravljanja.

Dinamika isplata ESI fondova vrlo je neujednačena među državama (vidi graf 1), što nije iznenađenje početkom proračunskog razdoblja, ali je dinamika isplata $u$ odnosu na planirana sredstva nakon prve dvije godine sve različitija među državama. Krajem 2019. godine, taj raspon se kretao između 32,6\% u Slovačkoj do 48,5\% u Estoniji. Nije ni za očekivati identičnu dinamiku iskorištenosti sredstava fondova EU po državama tijekom vremena, jer države imaju i različite prioritete ulaganja i različiti intenzitet ulaganja iz pojedinačnih fondova koji opet imaju različita implementacijska pravila i dinamiku provedbe.

Podaci iz toga grafa sugeriraju da su manje države, odnosno države s manjim gospodarstvima i manjim brojem stanovnika, a time i manjom alokacijskom sredstava fondova EU te manjom administracijom, proteklih godina uglavnom bilježile veći postotak implementacije sredstava fondova EU u odnosu na nešto veće države. Primjerice, Baltičke države, Cipar i Malta krajem 2017. godine, krajem 2018. godine i krajem 2019. godine nalaze se u gornjem dijelu tablice uspješnosti. U tim državama su izmjene u sustavu upravljanja fondovima EU u pravliu išle prema smanjenju broja operativnih programa te prema centralizaciji sustava i jasnijim procedurama provedbe programa i projekata regionalne politike EU, što se ukratko predstavlja u idućem poglavlju. 
Graf 1. Napredak u implementaciji Europskih strukturnih i investicijskih fondova, isplaćeno kumulativno, \% u odnosu na planirano (za proračunsko razdoblje EU 2014. 2020.)

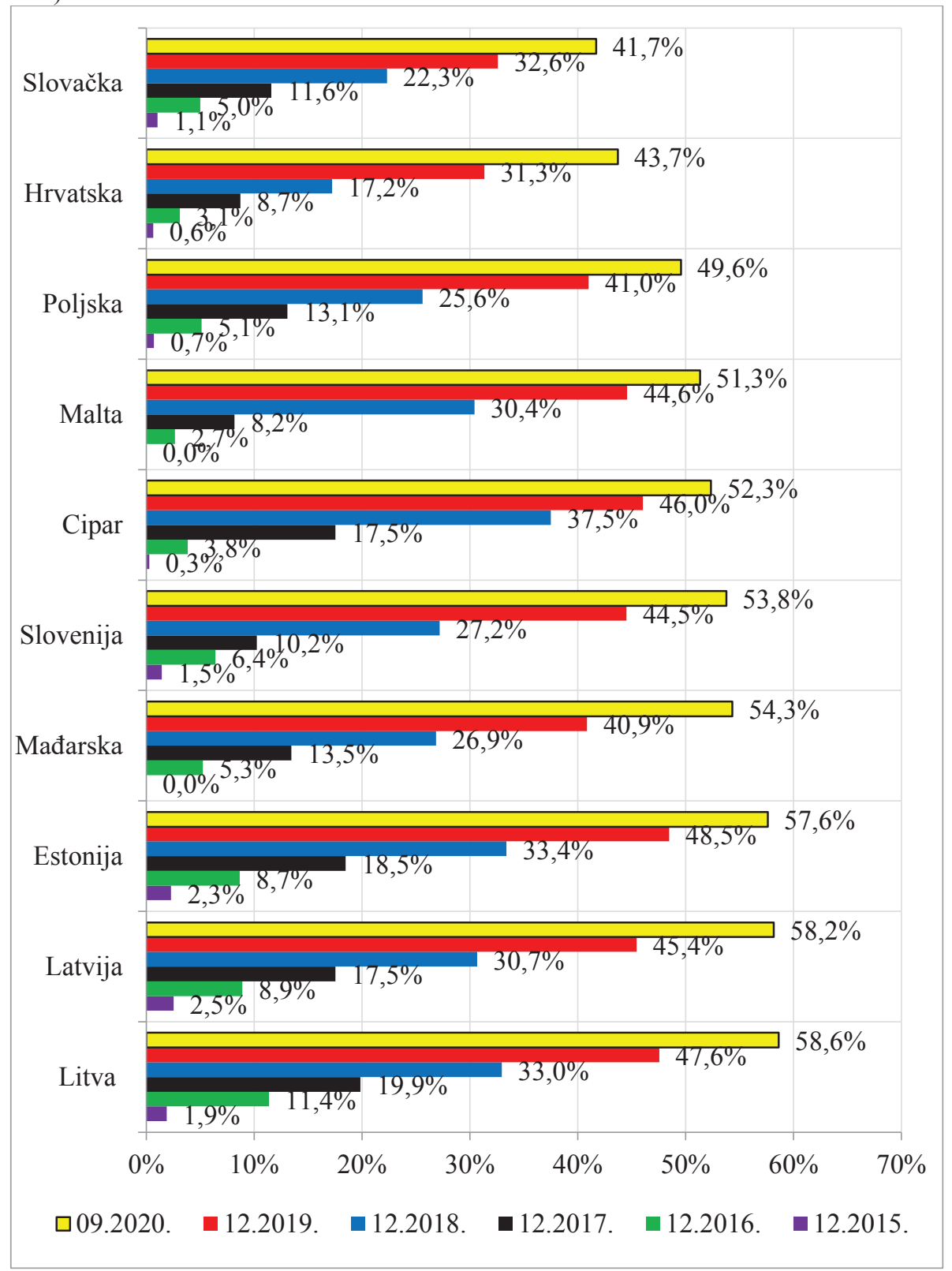

Izvor: Europska komisija, obrada i izračuni autora 


\section{OSVRT NA PROMJENE U SUSTAVIMA UPRAVLJANJA FONDOVIMA EU U ANALIZIRANIM DRŽAVAMA}

Promjene u sustavu upravljanja fondovima regionalne politike EU u nekoj državi korisnici su u pravilu rijetke tijekom trajanja sedmogodišnjeg proračunskog razdoblja EU. Naime, za navedeno razdoblje sustav upravljanja u nekoj državi se formira temeljem relevantnih uredbi (primjerice, za proračunsko razdoblje 2014. - 2020. Riječ je o Uredbi EU 1303/2013, a za proračunsko razdoblje 2021. - 2027. o Uredbi EU 375/2018) temeljem koje je definirano koje institucije (upravljačka tijela, koordinacijsko tijelo, posrednička tijela, revizorsko tijelo, tijelo za ovjeravanje) i s kojim funkcijama je potrebno ih imati i imenovati, a kako bi se mogli pripremati i provoditi programi i projekti vezani uz fondove regionalne politike EU u pojedinoj državi.

U proračunskom razdoblju 2014. - 2020. u svakoj od država analiziranih u ovom radu došlo je do određenih prilagodbi u sustavu upravljanja u odnosu na proračunsko razdoblje EU 2007. - 2013., ali iz različitih razloga te su promjene bile različitih intenziteta. Osvrt promjena u sustavima upravljanja pojedinih zemalja potvrđuje da su se sustavi prilagođavali potrebama, odnosno prilagođavali su se sa svrhom povećanja efikasnosti.

U slučaju Latvije, prethodni sustav upravljanja ocijenjen je kao vrlo kompleksan, s nejasnim podjelama kompetencija i nedovoljno usklađenim procedurama odgovornih institucija. Latvija je stoga analizom prethodnog sustava i naučenih lekcija napravila značajnije promjene u sustavu upravljanja za razdoblje 2014. - 2020., koji je značajnije centraliziran. Uspostavljeno je samo jedno upravljačko tijelo (u odnosu na dotadašnjih sedam), značajno je sužen opseg nadležnosti posredničkih tijela te su dužnosti jasnije definirane, a broj posredničkih tijela druge razine smanjen je na jedan. Glavnim nedostacima sustava upravljanja i kontrole 2007. - 2013. ocijenjeni su prekompliciranost sustava, nejasna raspodjela odgovornosti i zadaća, nejednakost u pristupu i praksi posredničkih tijela razine 2 (što je utvrđeno kao glavni nedostatak tadašnjeg sustava), različita razina kvalificiranosti (stručnih/administrativnih kapaciteta) tijela u sustavu. Nakon provedenih promjena, ključne razlike u sustavu prethodnog i tekućeg financijskog razdoblja su: uspostavljen samo jedan PT2, umjesto sedam PT2 kako je to bilo u razdoblju 2007. - 2013.

Litva je imala problema u funkcioniranju upravljačkih tijela te su uspostavljena nova, što je podrazumijevalo izmještaj određenih funkcija i odgovornosti među ministarstvima i agencijama. Ukratko, u odnosu na prethodno proračunsko razdoblje, $\mathrm{u}$ razdoblju 2014. - 2020., zabilježene su iduće promjene: Uspostavljena su nova posrednička tijela (Ministarstvo energetike, Ministarstvo kulture, Agencija za razvoj javnih investicija), pojačani su administrativni kapaciteti putem izravnog sudjelovanja potpornih institucija (Služba za istraživanje financijskog kriminala, Vijeće za konkurentnost), provedeni su izmještaji određenih funkcija i odgovornosti među ministarstvima i agencijama (u fazi projektnog vrednovanja uklonjene su određene procjene).

Estonija se poslužila Latvijskim iskustvima te je također centralizirala aktivnosti, a smanjila je i broj operativnih programa s tri na jedan. Time je smanjeno 
administrativno opterećenje, što je bitna stavka u provedbi EU fondova u manjim državama (poput Baltičkih država te Cipra i Malte), gdje je ograničenje u ljudskim kapacitetima izraženije nego u većim državama te rizik obavljanja veće širine poslova izraženiji nego u većim državama. Razlozi spomenutih promjena u strukturi upravljanja mogu se svesti na iduće: Estonija je ,inspirirana“ Latvijskim modelom te je nastojala centralizirati i usmjeriti administrativne procese.

Malta je i u prethodnom proračunskom razdoblju EU imala izraženo centralizirani sustav upravljanja, što joj nije dalo prostora za veće izmjene u sustavu upravljanja, niti je za to bilo veće potrebe. Stoga je glavna promjena u sadašnjem, u odnosu na prethodno proračunsko razdoblje (2007. - 2013.), uvođenje elektronske prijave aplikacija kako bi se povećala učinkovitost usmjeravanja i trošenja sredstava. Ukupni napori za povećanje efikasnosti rezultirali su i povećanjem pomoći aplikantima, odnosno korisnicima (primjerice putem proširenja postojećih „help desk-ova“) pojednostavljenjem procesa odabira (selekcije) i jačanjem administrativnih kapaciteta $\mathrm{i}$ stručnjaka u procesu odabira (selekcije) projekata.

Administrativno opterećenje i potreba za održavanjem centralizacije bila je prisutna i u Cipru. Stoga su se u novom proračunskom razdoblju neke administrativne kontrole potrošnje sredstava za sufinanciranje javne nabave centralizirale putem državne riznice (dok je u prethodnom proračunskom razdoblju to bio zadatak posredničkih tijela). Dodatno, pojednostavljene su procedure upravljanja i kontrole (putem izuzimanja od sudjelovanja paralelnih razina nadležnosti i kontrola, potom koncentriranja provedbe procedura od strane institucija koje imaju primjereno iskustvo i administrativni kapacitet), jer su stvarale pritisak na administrativne kapacitete i utjecale su na implementaciju projekta, što je sličan proces kao što je zabilježen u Baltičkim državama.

\section{ZAKLJUČAK}

Prilagodba institucionalnog sustava za provedbu fondova regionalne politike $\mathrm{u}$ Hrvatskoj, a za proračunsko razdoblje EU 2021. - 2027., može se temeljiti dijelom i na iskustvima drugih država koje su prilagođavale svoj sustav upravljanja, kako bi povećale efikasnost. Tu se prije svega može naglasiti primjer iskustva Baltičkih zemalja. Znakovito je da su od početka sedmogodišnjeg proračunskog razdoblja EU (2014. - 2020.), tri Baltičke države nalazile među četiri najbolje države (od analiziranih deset država središnje i istočne Europe, uključujući Hrvatsku) gledajući isplate sredstava fondova EU u odnosu na dodijeljena sredstva. Svim državama je zajedničko da u sustavu upravljanja fondovima EU imaju samo jedno upravljačko tijelo (ministarstvo financija) za provedbu regionalne politike, a u slučaju Litve (koja ima najveću alokaciju sredstava regionalne politike od svih Baltičkih zemalja, postoji i koordinacijsko tijelo.

Dodatno, sve tri države imaju samo po jedan nacionalni operativni program za provedbu regionalne politke EU. U slučaju Litve i Estonije, to je smanjenje za dva operativna programa u odnosu na prethodno proračunsko razdoblje (2007. - 2013.), dok je Latvija i u tom razdoblju imala jedan operativni program. Dodatno, Latvijski model 
korišten je za promjene u sustavu upravljanja u Estoniji za razdoblje 2014. - 2020., čime se nastojao centralizirati sustav i administrativne procese učiniti učinkovitijima.

Stoga sustavi upravljanja među državama nisu identični, ali imaju sličnosti koje su dijelom posljedica prijenosa iskustava među državama (primjer Estonije). Navedeno pokazuje da je opravdan zaključak da je moguće definirati optimalan i funkcionalan institucionalni sustav za provedbu fondova regionalne politike, koji se temelji na sustavima u ovom radu analiziranih i usporedivih država EU i primijeniti ga na Hrvatsku.

\section{LITERATURA:}

1. Arratibel, O. i ostali (2007.). Determinants of growth in the central and eastern european EU member states - a production function approach, Occasional Paper Series, no. 61, European Central Bank.

2. Ascani, A., Crescenzi, R., Iammarino, S. (2012.). New Economic Geography and Economic Integration: A Review

3. Background study for the Preparation of the Implementation Structure for the 2021+ Period, final report (Annex 2 to the Final Report), Ernst \& Young s.r.o., 2019.

4. Bianchi, P. \& Labory, S (eds) (2006). International Handbook on Industrial Policy, Edward Elgar, Cheltenham.

5. Borović, Z., Rebić, M., Tomaš, D. (2020). Total factor productivity drivers in the selected EU countries: cointegration approach, Proceedings of Rijeka Faculty of Economics and business: Journal of Economics and Business, 38 (1), str. 295-315

6. Borys, M. M., Polgár, K., Zlate, A. (2008.). Real convergence and the determinants of growth in EU candidate and potential candidate countries: a panel dana approach, Occasional Paper Series, no. 86, European Central Bank

7. (March 2015), Operational Programme I, Fostering a competitive and sustainable economy to meet our challenges, Cohesion policy 2014-2020, str. 313; Dostupno na: https://eufunds.gov.mt/en/Operational\%20Programmes/Programming\%20Perio $\mathrm{d} \% 202014 \% 20-$ \%202020/Operational\%20Programme\%201/Documents/Adopted\%20OPI(ff).p $\underline{\mathrm{df}}$

8. Eurostat regional yearbook, 2016 edition, Brussels, 14.12.2015 COM(2015) 639 final, COMMUNICATION FROM THE COMMISSION, Investing in jobs and growth - maximising the contribution of European Structural and Investment Funds

9. European Commission, Brussels (2014), Summary of the Partnership Agreement for Cyprus, 2014-2020

10. Eurostat regional yearbook 
11. Ferry, M., McMaster, I. (2013.). Cohesion Policy and the Evolution of Regional Policy in Central and Eastern Europe, Europe-Asia Studies, vol. 65, no. 8, Routledge, str. 1502-1528

12. Directorate General for Internal Policies of the Union (2018), Financial Implementation of European Structural and Investment Funds, dostupno na : https://www.europarl.europa.eu/RegData/etudes/STUD/2018/621785/IPOL_S TU(2018)621785_EN.pdf

13. Frkić, I., Rek, Lj. (2004.). Sposobnost korištenja sredstava pretpristupnih fondova EU: iskustva država kandidatkinja i osvrt na RH. Ministarstvo za europske integracije

14. Jakubowski, A. (2018). Convegence or Divergence? Multidimensional Analysis of Regional Development in the New European Union Member States, Barometr Regionalny, vol. 16, no. 1, str. 31-40

15. Korištenje EU fondova po državama (dostupno na: https://cohesiondata.ec.europa.eu/countries/ pristupljeno stranici: 31. siječnja 2021.)

16. Management authorities of EU funds implementation system in EU countries (dostupno na http://ec.europa.eu/regional_policy/en/atlas/managingauthorities $/ /$ ? search $=1 \&$ keywords $=\&$ periodId $=3 \&$ countryCode $=$ LV\&typeId $=\mathrm{A}$ $\underline{\mathrm{LL}}$

http://ec.europa.eu/regional_policy/en/atlas/managingauthorities $/ /$ ? search $=1 \&$ keywords $=\&$ periodId $=3 \&$ countryCode $=$ SK\&typeId $=\mathrm{N}$ $\underline{\mathrm{AT}++}$

http://ec.europa.eu/regional policy/en/atlas/managingauthorities//? search $=1 \&$ keywords $=\&$ periodId $=3 \&$ countryCode $=$ SI\&typeId $=\mathrm{N}$ $\underline{\mathrm{AT}}++$

http://ec.europa.eu/regional_policy/en/atlas/managingauthorities//?search=1\&keywords=\&periodId=3\&countryCode=HU\&typeId= NAT ++ pristupljeno stranici 31. siječnja 2021)

17. Maskell, P., Eskelinen, H., Hannibalsson, I. et al. (1998). Competitivness, Localised Learning and Regional Develeopment: Specialisation and Prosperity in Small Open Economies. London: Routeledge.

18. Monfort, P. (2008). Convergence of EU regions Measures and evolution, Working papers, European Union Regional Policy, broj 1

19. Martin, C., Veláquez, F. J., Funck, B. (2001). European integration and income convergence - lessons for Central and Eastern European countries, World Bank technical paper, no. WTP 514, Washington, D.C.: World Bank Group

20. (2014): Partnership Agreement of Malta, 2014-2020

21. Razvojne razine država:

(http://ec.europa.eu/eurostat/tgm/table.do?tab=table\&init=1\&language=en\&pc $\underline{\text { ode }=\text { tec00114\&plugin }=1}$ pristupljeno stranici 31. siječnja 2021) 
22. Radulović, M., Kostić, M. (2020). Globalization and economic growth of Eurozone economies, Proceedings of Rijeka Faculty of Economics and business: Journal of Economics and Business, 38 (1), str. 183-214

23. Strielkowski, W., Höschle, F. (2013). Evidence for economic convergence in the EU: the analysis of past EU enlargements, Technological and economic development of Economy, vol. 22, no. 4, Routledge, Taylor \& Francis Group, str. 617-630

24. Zbigniew, M., Mariusz, P. (2004). Real economic convergence in the EU accession countries, International Journal of Applied Econometrics and Quantitative Studies, vol. 1-3, str. 5-38 


\title{
EU REGIONAL POLICY FUND MANAGEMENT SYSTEMS IN SMALL COUNTRIES - EXPERIENCES OF THE BALTIC SEA AND BALTIC ISLANDS' COUNTRIES AND THEIR APPLICABILITY TO CROATIA
}

\author{
Zvonimir Savić
}

\section{Summary}

National systems that enable smooth management and efficient implementation of EU regional (cohesion) policy funds are crucial for the successful use of this policy in individual EU countries. However, the framework for diversity in the implementation and management of EU regional policy is extensive. Therefore, national experiences differ due to various factors, such as the intensity and type of EU funding, the coherence of the areas into which EU funds are channelled, and the relative strength of national administration. Therefore, implementation systems can differ significantly between countries, and the collection and processing of data for the purposes of this paper are significantly hampered by the unequal transparency and availability of data on the structure of national institutional EU fund management systems. The research results in this paper have shown that the systems (structure) of the EU regional policy funds' management between countries are not identical due to a whole range of factors. However, similarities between countries analysed in this paper are also present, which is partly due to the transfer of experiences between countries. Therefore, the results of the research show that it is possible to define an optimal and functional national system of managing EU regional policy funds, based on the experiences of comparable countries and to apply it to Croatia. Given that we are at the very beginning of the new EU Multiannual Financial Framework (2021-2027), when EU fund management systems are defined by EU member states for a new financial perspective, and published papers/research that would be the basis for such decisions on the level of Croatia are absent, thus the contribution and value of this paper for policyholders is well-timed and significant.

Keywords: EU regional policy; EU regional policy management systems; disbursement of EU funds; absorption of EU funds. 